\title{
Community analysis of aggregated bacteria in southern Lake Baikal
}

\author{
T.S. AHN ${ }^{1}$, S.O. JEON ${ }^{1}$, O.S. KIM ${ }^{1}$, L.P. SPIGLAZOV ${ }^{2}$, V.V. DRUCKER ${ }^{2}$ and \\ S.H. HONG ${ }^{1}$
}

${ }^{1}$ Kangwon National University, Chunchon, 200-701, Korea

${ }^{2}$ Limnological Institute, Russia Academy of Science, Irkutsk, Russia

\begin{abstract}
The main aim of this study is to unveiling the community structure of aggregated bacteria in lake Baikal and determining the relations with free-living bacteria. For achieving this aim, FISH method was applied to free-living and aggregated bacteria in Lake Baikal at April, 2001. Bacterial counts of free-living bacteria by DAPI staining ranged from 0.2 $\times 10^{6}$ to $3.2 \times 10^{6}$ cells $\cdot \mathrm{ml}^{-1}$, which decreased with depths, whereas aggregated bacterial numbers dramatically increased with depths, ranged from $0.4 \times 10^{4}$ to $3.3 \times 10^{4}$ cells $\mathrm{ml}^{-1}$. Also, the ratios of EUB probe binding cells to DAPI counts ranged from 52.3 to $74.1 \%$ in free-living bacteria, from 39.6 to $66.7 \%$ in aggregated bacteria, respectively. Community composition of aggregated bacteria was very different from free-living bacteria. Especially, that is remarked at $25 \mathrm{~m}$ depth which is observed the highest value of phytoplankton. The vertical profile of aggregated bacteria community was very particular. $\beta$-Proteobacteria was increasing with depth till $100 \mathrm{~m}$. In $250 \mathrm{~m}$ depth, $\gamma$-Proteobacteria was $44 \%$ of DAPI bound cells, while other groups were less than $1 \%$. In conclusion, the bacterial community structures of free-living and aggregated bacteria were very different, and they sustain the independent ecosystem separately
\end{abstract}

Key words: In situ hybridization, aggregated bacteria, Lake Baikal, free-living bacteria;

\section{Introduction}

Bacteria can be classified as free-living and attached bacteria in lake ecosystem by habitat condition. The aggregated bacteria are often larger, and are present in higher local concentration and more active on a per-cell bases than free-living bacteria in surrounding bulk water (Griffith et al., 1994), and higher specific exoenzyme activities have also been found with macroaggregates (Karner and Herndl, 1992). Therefore they could have an important role in carbon cycling in aquatic ecosystem.

Recently, new molecular techniques such as fluorescent in situ hybridization (FISH) with group-specific fluorescent-labeled probes are simple and quick to apply for defining bacterial communities (Wagner et al., 1993). The main aim of this study is unveiling the community structure of aggregated bacteria in Lake Baikal and determining the relations with free-living bacteria. For achieving this aim, FISH method was applied to free-living and aggregated bacteria in southern Lake Baikal at April 2001, just after the thawing. 


\section{Materials and Methods}

Sampling station is situated in the Listvyanichnaya Bay in $2 \mathrm{~km}$ from Southern Baikal Krestovaya. Samples were collected from 0, 10,25,50,100,250m depths with a Van-Dorn sampler on April 2001. All samples fixed with $4 \%$ paraformaldehyde solution were transported to laboratory with cool condition, and stored at $4^{\circ} \mathrm{C}$ until further processing.

Analyses of bacterial community were carried out with the FISH(fluorescent in situ hybridization) method by using probes labeled with tetramethylrhodamine to targeted $16 \mathrm{~S}$ and $23 \mathrm{~S}$ rRNA. We used the EUB338 probe for domain bacteria, ALF1b probe for $\alpha$-subclass, BET42A probe for $\beta$-subclass, GAM42a probe for $\gamma$-subclass of Proteobacteria, CF probe for Cytophaga-Flavobacterium group and PLA probe for Plancktomycetales (Amann et al, 1992; Manz et al, 1992). Detailed methods are described in article of Weiss et al (1996).

\section{Results}

\section{Bacterial numbers}

Counts of free-living bacteria were fairly similar, which were $3.1 \times 10^{6}$ and $3.2 \times 10^{6}$ cells $\mathrm{mL}^{-1}$ at 0 and $10 \mathrm{~m}$ depths, and showed $1.0 \times 10^{6}$ and $1.3 \times 10^{6}$ cells $\mathrm{mL}^{-1}$ at 25 and $50 \mathrm{~m}$ depths, respectively, it showed the minimum numbers $0.2 \times 10^{6}$ cells $\mathrm{mL}^{-1}$ at $250 \mathrm{~m}$ depth. Total bacterial numbers of free-living bacteria decreased gradually with depths. Whereas aggregated bacterial numbers increased with depths, which were ranged from $0.4 \times 10^{4}$ to $3.3 \times 10^{4}$ cells $\mathrm{mL}^{-1}$. The highest abundances were observed as $3.3 \times 10^{4}$ cells mL ${ }^{-1}$ at 250m (Fig. 1).

\section{Bacterial community analysis}

Vertical distribution of community structure is shown in Fig. 2. The community structure of free-living bacteria at $0 \mathrm{~m}$ was very similar to that of $10 \mathrm{~m}$. Proportions of $\beta$ - and $\gamma$-Proteobacteria ranged from 12.8 to $13.3 \%$ and from 22.5 to $23.1 \%$ at 0 and $10 \mathrm{~m}$ depths respectively. The ratios of $\beta$ - and $\gamma$ -Proteobacteria decreased at $25 \mathrm{~m}$ depth, which were 9.9 and $5.9 \%$, respectively. Both two groups decreased gradually with depths. The $\alpha$-Proteobacteria, Cytophaga-Flavobacterium group and Plancktomycetales were relatively very low proportions, less than $5 \%$ between 0 and $50 \mathrm{~m}$. But At $100 \mathrm{~m}$ depth, propor-

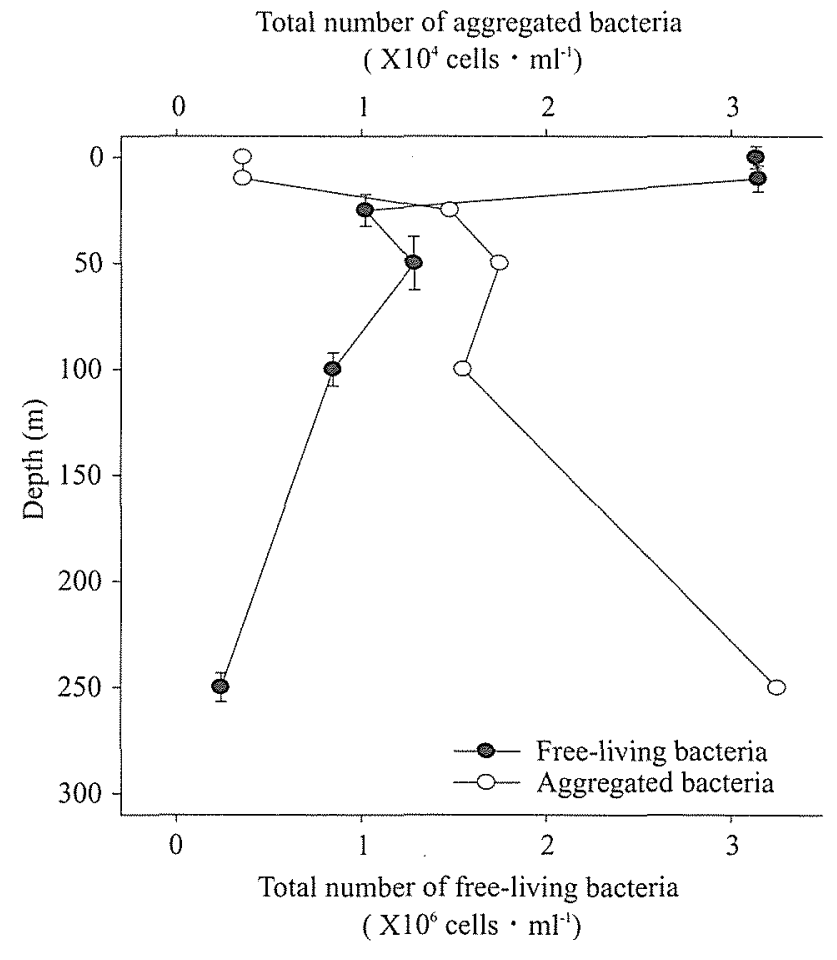

Fig. 1. Vertical profiles of bacterial numbers of free living and aggregated bacteria in Lake Baikal on April 2001. 
tions of $\alpha$-Proteobacteria and Plancktomycetales were slightly increasing by 10.8 and $7.4 \%$, respectively. Community compositions of all groups were similar at $250 \mathrm{~m}$ depth, which ranged from 1.8 to $6.5 \%$. According to majority of our result, the proportion of Unknown- Eubacteria which is not bound to any probes except EUB338, showed high range from 30.2 to $44.4 \%$, which were slightly increased with depths (Fig. 2). In case of aggregated bacteria, the proportions of all Eubacteria group were ranged from 0.2 to $10.6 \%$ at 0 and $10 \mathrm{~m}$ depths, which were similar to those of freeliving bacteria. But at $25 \mathrm{~m}$ depth, the ratios of $\beta$ - and $\gamma$-Proteobacteria increased in 14.3 and $14.1 \%$, which were different from those of free-living bacteria, whereas CytophagaFlavobacterium group decreased in $2.2 \%$. Interestingly, $\beta$-Proteobacteria drastically increased in $52 \%$ at $100 \mathrm{~m}$ depth but at $250 \mathrm{~m}$ depth, $\gamma$-Proteobacteria dominated as $44 \%$. These structures were fairly different from those of free-living bacteria. The ratios of Unknown-Eubacteria were ranged from 9.1 to $26.3 \%$, which were considerably lower than those obtained from free-living bacteria (Fig. 3).

\section{Discussion}

The relationship between free-living and aggregated bacteria could be hypothesized like following. First hypothesis is that both two bacterial communities are different from each other, and strictly there is no 
relationship between two communities. Second hypothesis is that the bacteria occasionally is attaching to newly formed particles and proliferating on the surface. And later, secondary and other invaders cover the microcolony. Most aquatic bacteria attached to nonbiotic and dead particles with "non-specific" mechanism, and "specific adhension" to living material (Bayer et al, 1996). Also, on cellulose film, the bacteria reversely attached at early stage and later, bacteria groups are changing with irreversely attaching bacteria (Hong et al, 1999). These preliminary observations suggest that the environment of aggregated bacteria may not have close similarities to free-living bacteria with respect to microbial colonization. In this study, the numbers and community structures were quietly different from each other.

The composition of bacterial community could be influenced by attachment substratum, by associated environmental conditions, by other biota such as grazer and organic mater supplier and adhesion ability (Hong et al, 1999). With this fact, the community structure could be explained like followings. At 0 to $25 \mathrm{~m}$ depths, where the chlorophyll $a$ value was about $1.5-3.1 \mathrm{ug} / \mathrm{l}$, the exudates from phytoplankton stimulate the pelagic bacteria. And to living phytoplankton, the coupling bacteria (Sell, 1993) are attached by 'specific adhesion' mechanism (Fletcher, 1996). And to non- living and dead particles the bacteria attached reversibly. These bacterial communities would start to change into irreversible aggregated bacteria (Vandevivere and Kirchman, 1993). Below $50 \mathrm{~m}$ depth, where no phytoplankton exists, and organic materials must come from upper layers and aggregates, numbers of free-living bacteria are decreasing and proportions of Unknwon Eubacteria group are increasing because of limitation of available organic mater and nutrients. But the aggregated bacterial communities are changing by secondary and other invaders.

In conclusion, the bacterial community structures of free-living and aggregated bacteria were very different, and they sustain the independent ecosystem separately. Differences in rates of polymer hydrolysis, substrate uptake and assimilation, biomass production, and predation for attached and free-living bacteria may result in considerably different roles for these communities in material and energy transfer in Lake Baikal.

\section{Acknowledgments}

This work was supported by a research grant from the Korea Science and Engineering Foundation (2000-201-02-2)

\section{References}

Amann, R.I., Stromely, J., Devereux, R, Key, R. and Stahl, D.A. (1992) Molecular and microscopic identification of sulfate-reducing bacteria in multispecies biofilms. Appl. Environ. Microbiol., 58:614-623.

Bayer, E.A., Shohan, Y., Tormo, J., and Lamed, R. (1996) The cellulosome: A cell surface organelle for the adhesion to and degradation of cellulose. In: John Wiley and Sons Inc., Fletcher, M.(eds) Bacterial adhesion. N.Y., 155-182 pp

Fletcher, M. (1996) Bacterial attachment in aquatic environments: A diversity of surfaces and adhesion strategies. In: John Wiley and Sons Inc., Fletcher, M.(eds) Bacterial adhesion. N.Y., 1-24 pp

Griffith, P., Shiah, F., Gloersen, K., Ducklow, H.D. and Fletcher, M. (1994) Activity and distribution of 
attached bacteria in Chesapeake Bay. Mar. Ecol. Prog. Ser, 108:1-10.

Karner, M., and Herndl, G.J. (1992) Extracellular enzymatic activity and secondary production in freeliving and marine-snow-associated bacteria. Mar: Biol., 113:341-347

Manz, W., Amann, R., Ludwig, W. and Wagner, M. (1992) Phylogenetic oligodeoxynucleotide probes for the major subclasses of Proteobacteria: problems and solutions. Appl. Environ. Microbiol., 15: 593-600.

Sell, A.F. (1993) Phytoplankton excreted organic carbon. In: Springer-Verlag, J.Overbeck and R.J. Chróst (eds), Microbial Ecology of Lake Plußsee. N.Y. 81-91pp.

Wagner, M., Amann, R., Lemmer, H., and Schelifer, K.H. (1993) Probing activated sludge with oligonucleotides specific for Proteobacteria: Inadequacy of culture-dependent methods for describing microbial community structure. Appl. Environ. Microbiol., 59:1520-1525.

Weiss, P., Schweitzer, B., Amann, R., and Simon, M. (1996) Identification in situ and dynamics of bacteria on limnetic organic aggregates (Lake Snow). Appl. Environ. Microbiol., 62:1998-2005.

Vandevivere, P., and Kirchman, D.L. (1993) Attachment simulates exopolysaccharide synthesis by a bacterium. Appl. Environ. Microbiol., 59:3280-3286. 